\title{
BMJ Global Health Increasing tuberculosis burden in Latin America: an alarming trend for global control efforts
}

\author{
Otavio T Ranzani (D , , ${ }^{1,2}$ Julia M Pescarini, ${ }^{3,4}$ Leonardo Martinez, ${ }^{5}$ \\ Alberto L Garcia-Basteiro ${ }^{6,7}$
}

\begin{abstract}
'Of concern is the WHO Region of the Americas, where incidence is estimated to be slowly increasing after many years of decline, owing to an upward trend in Brazil during 20162019.'-2020 Global TB report.
\end{abstract}

To cite: Ranzani OT, Pescarini JM, Martinez L, et al. Increasing tuberculosis burden in Latin America: an alarming trend for global control efforts. BMJ Global Health 2021;6:e005639. doi:10.1136/ bmjgh-2021-005639

Handling editor Seye Abimbola

- Prepublication history and additional material is published online only. To view please visit the journal online (http://dx. doi.org/10.1136/bmjgh-2021005639).

Received 8 March 2021 Accepted 9 March 2021

Check for updates

(c) Author(s) (or their employer(s)) 2021. Re-use permitted under CC BY-NC. No commercial re-use. See rights and permissions. Published by BMJ.

For numbered affiliations see end of article.

Correspondence to Dr Otavio T Ranzani; otavio.ranzani@isglobal.org
On the 24 March, we will commemorate the World TB Day. Despite important achievements on tuberculosis (TB) control summarised in the 2020 WHO Global TB report, ${ }^{1}$ the above quotation referring to the WHO Region of the Americas is concerning. In contrast with global decreases in TB incidence rates over the past decade, in 2019, the Region of the Americas has taken a step backwards and the TB incidence rate has shown an unexpected upturn in recent years (online supplemental efigure-1 in the supplemental

The Region of the Americas comprises 46 countries and territories and Brazil and Peru are among the WHO high-TB burden countries. To illustrate the recent increase in $\mathrm{TB}$ incidence in the region, we selected 12 countries from Latin America (Argentina, Brazil, Chile, Colombia, Ecuador, El Salvador, Mexico, Panama, Paraguay, Peru, Uruguay and Venezuela), which account for approximately $80 \%$ of the total estimated TB cases in the region. Using data from WHO TB databases (exported on 22 October 2020), we show that, between 2014 and 2019, the estimated TB incidence rate increased from 38.4 to 41.7 per 100000 ( $8.6 \%$ relative increase) and the estimated number of incident cases increased from 202290 to 230100 (27 810 more cases, $13.8 \%$ relative increase) for these 12 countries (figure 1, for the same data in separated panels by each country, please see online supplemental eFigure-2 in the supplemental file).

This worrying scenario, in the context of elimination strategies in other continents, should not go unnoticed without clear action. file).
Several factors may play a role in this resurgence. In recent years, Latin America is facing economic, social and political crises, increasing population vulnerabilities to acquire and progress to TB disease in several ways. TB is, unfortunately, a marker of social inequity and the paradigm of poverty-related diseases; with the most vulnerable populations typically enduring the highest burden. ${ }^{1}$ In Latin America, poverty has decreased from 230 million $(45.4 \%)$ to 164 million persons $(27.8 \%)$ between 2002 and 2014. However, since 2015, poverty has begun to increase, reaching 191 million $(30.8 \%$ ) in 2019 , an additional of 27 million persons returning to poverty compared with $2014 .^{2}$ Venezuela and Brazil were the main drivers of these increases. In addition, other indicators of vulnerability have also surged: more than 4 million residents from Venezuela have migrated to neighbouring countries since $2014 .^{3}$ Furthermore, the number of persons experiencing homelessness has doubled from 2012 to 2019 in Brazil. ${ }^{4}$ Finally, incarcerated prison populations have increased by $206 \%$ across Central and South America between 2000 and 2018. ${ }^{56}$

Venezuela has seen the most dramatic upward trend in TB incidence, almost doubling from 26.6/100 000 in 2014 to 45.6/100 000 in 2019 (figure 1). In Argentina, incidence rates declined from 38.0/100 000 in 2000 to $20.5 / 100000$ in 2010, but the country's progress has receded and experienced a $41.5 \%$ relative increase from 2010 to $2019(29.0 / 100000$ on 2019). Uruguay also shows a continuous increase in TB incidence rate since 2007. In Brazil, the estimated incidence increased from 42.9/100 000 in 2014 to $45.5 / 100000$ in 2019 (6.1\% relative increase), representing approximately 9000 additional incident cases.

National Tuberculosis Programmes, the Pan American Health Organization, and other national and international institutions 

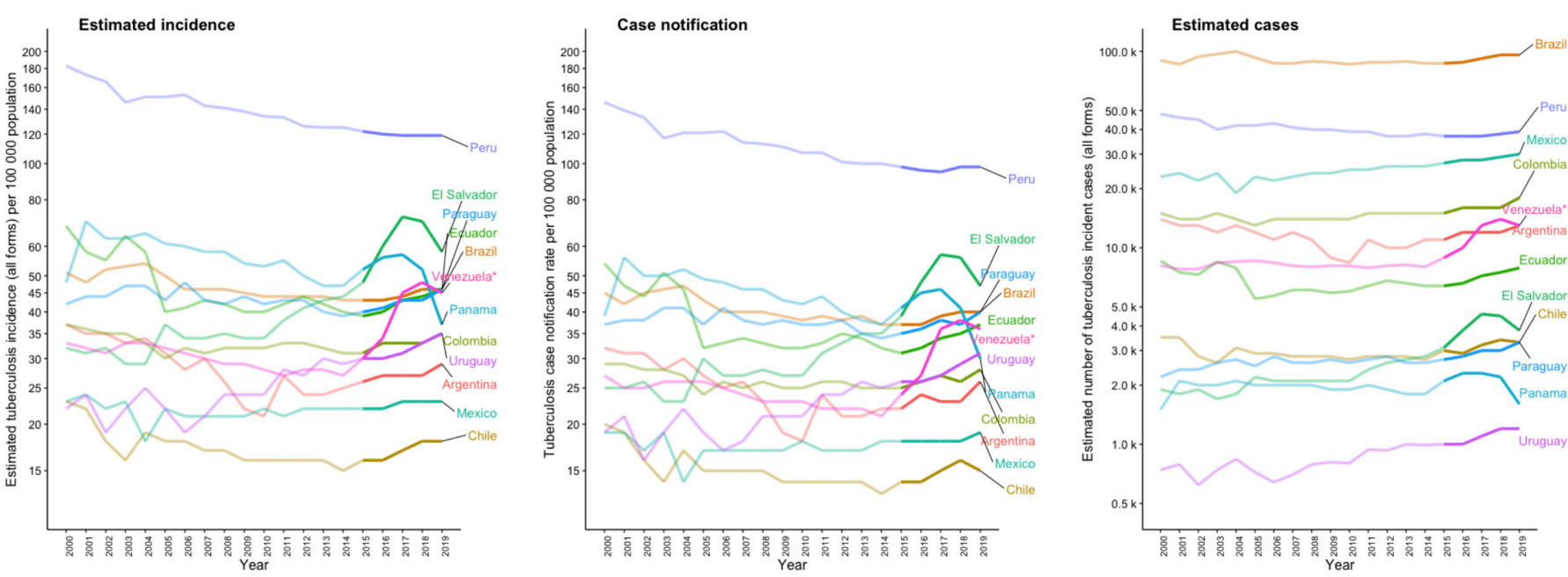

Figure 1 Estimated incidence rate, case notification rate and estimated incident cases of tuberculosis for 12 countries in Latin America between 2000 and 2019. Data generated from the tuberculosis WHO most updated database, exported on 22 October 2020. *Venezuela stands for Bolivarian Republic of Venezuela.

have made a huge effort on TB control in Latin America. In recent years, several countries have become ineligible for certain international donors (eg, Global Fund), partially because of their socioeconomic development, but also because of recent TB control successes. Therefore, retaining investments in $\mathrm{TB}$ control in the region is critical.
A first step to mitigate the health impact of this recent trend is to disentangle its main drivers (table 1 ). It is likely this resurgence is due to multiple factors and should be within the framework of already known TB drivers. ${ }^{1}$ Researchers, academics and National TB programmes should take advantage of TB morbidity and mortality surveillance to describe where recent increases

Table 1 A proposed framework for initial areas of research to understand and mitigate the recent increase of tuberculosis in Latin America

\begin{tabular}{|c|c|c|}
\hline Area & Questions & Actors \\
\hline Theoretical & $\begin{array}{l}\text { What are the actions and pathways } \\
\text { responsible for the recent increase of } \\
\text { TB in Latin America? }\end{array}$ & $\begin{array}{l}\text { To establish theoretical models aiming to explain the phenomenon, } \\
\text { describe the complex interactions and support the analysis of causal } \\
\text { research questions }\end{array}$ \\
\hline Descriptive & $\begin{array}{l}\text { When, where and how much is } \\
\text { occurring the recent increase in TB } \\
\text { incidence? }\end{array}$ & $\begin{array}{l}\text { To describe the time series of TB cases/incidence stratified by } \\
\text { demographic features such as age and sex, regions and groups of interest } \\
\text { To quantify the trend of the increased incidence in TB in relative (ie, } \\
\text { growth rate) and absolute measures }\end{array}$ \\
\hline Epidemiology & $\begin{array}{l}\text { What are the main drivers of recent } \\
\text { increase in TB incidence? }\end{array}$ & $\begin{array}{l}\text { To evaluate factors associated with the recent increase in TB using } \\
\text { ecological data } \\
\text { To quantify the contribution of factors on the relative increase of TB } \\
\text { incidence using individual population data } \\
\text { To estimate the population attributable fraction (PAF) of each factor } \\
\text { associated with the TB increase and the combined risk factors } \\
\text { (intersectional approach) }\end{array}$ \\
\hline Modelling & $\begin{array}{l}\text { In a complex scenario, what } \\
\text { parameters could explain and } \\
\text { mitigate the recent increase in TB } \\
\text { incidence? }\end{array}$ & $\begin{array}{l}\text { To account for the several players and changes in the region, accounting } \\
\text { for its heterogeneity, to explain the observed phenomena } \\
\text { To simulate scenarios of potential interventions to mitigate the recent } \\
\text { increase and return to the phase of decreasing incidence } \\
\text { To evaluate cost-effective interventions in the short term and long term } \\
\text { to mitigate the recent increase and return to the phase of decreasing } \\
\text { incidence }\end{array}$ \\
\hline $\begin{array}{l}\text { Clinical } \\
\text { trials and } \\
\text { implementation }\end{array}$ & $\begin{array}{l}\text { Does the intervention } \mathrm{X} \text { could reduce } \\
\text { incidence of TB in the region? }\end{array}$ & $\begin{array}{l}\text { To evaluate better strategies to implement and optimise already known } \\
\text { interventions to reduce incidence of TB, taking account the particularities } \\
\text { of Latin America } \\
\text { To perform randomised interventions based on the main drivers aiming } \\
\text { to reduce the incidence of TB, focusing on prevention of transmission, } \\
\text { development of disease after infection and treatment } \\
\text { Health impact evaluation of new implementations }\end{array}$ \\
\hline
\end{tabular}

TB, tuberculosis. 
are occurring in terms of key demographic variables (eg, age and sex), geographical location within each country, ${ }^{7}$ and stratified by main groups of interest, such as those with HIV infection and prisoners. ${ }^{5-8}$ Additionally, studies with individual data, allowing for robust estimates of drivers on TB incidence in the region are needed. Other actions in the region should be considered because of their direct impact on improved diagnosis and notification of cases, such as roll out of platforms for molecular testing (GeneXpert), implementation of active contact tracing strategies and improved surveillance systems (quality and coverage) ${ }^{8-10}$ Additionally, research and surveillance should aim to characterise TB transmission dynamics using molecular tools. The introduction of new lineages or resurgence of new strains in the region could be associated with increased transmission, while going unnoticed. ${ }^{11}$ Finally, the use of modelling techniques may incorporate data on identified drivers associated with the observed upward trend in TB notifications in several Latin American countries, providing a better understanding and shedding light on mitigation opportunities.

The health and social impact of increasing TB burden in the region may be vast. Moreover, this worrying trend may by amplified by the impact of the current COVID-19 pandemic, which is expected to increase TB burden in the upcoming future. Irrespective of the negative impact of the COVID-19 pandemic in regional control efforts, TB is associated with considerable health burden not only on deaths and years of life lost, but also on comorbidities and subsequent quality of life during and after the TB episode. ${ }^{12} 13$ Increased health demand caused by post-TB lung disease is expected. ${ }^{13}$ Additionally, TB patients can experience exacerbation of previous chronic diseases, such as diabetes and chronic respiratory disorders. In this context, previous chronic diseases and recent sequelae from TB might have even worse treatment and control if we consider the catastrophic cost affecting patients and relatives that usually occurs during and after TB treatment. This scenario associated with the barriers to achieve universal health coverage in the region, ${ }^{14}$ can be amplified by the ongoing socioeconomic crisis and implementation of austerity measures in some countries of Latin America. ${ }^{15}$

The need to act on a multifaceted platform to tackle the resurgence of TB in Latin America is now urgent. We expect additional challenges for health systems coping with the ongoing COVID-19 pandemic and its sequelae, which are likely to continue to impact TB care. TB control in the Americas is likely to worsen in upcoming years if remedial, coordinated actions are not urgently implemented to reverse these trends. Otherwise, years of thorough efforts in TB control will be lost.

\section{Author affiliations}

${ }^{1}$ Barcelona Institute for Global Health, ISGlobal, Universitat Pompeu Fabra, CIBER Epidemiología y Salud Pública, Barcelona, Spain

${ }^{2}$ Pulmonary Division, Heart Institute (InCor), Hospital das Clinicas HCFMUSP,

Faculdade de Medicina, Universidade de Sao Paulo, Sao Paulo, Brazil
${ }^{3}$ Department of Infectious Disease Epidemiology, London School of Hygiene \& Tropical Medicine, London, UK

${ }^{4}$ Centre for Data and Knowledge Integration for Health (CIDACS), Instituto Gonçalo

Moniz, Fundação Oswaldo Cruz (FIOCRUZ), Salvador, Brazil

${ }^{5}$ Department of Epidemiology, School of Public Health, Boston University, Boston, Massachusetts, USA

${ }^{6}$ Barcelona Institute for Global Health, ISGlobal, Hospital Clínic-Universitat de Barcelona, Barcelona, Spain

${ }^{7}$ Centro de Investigação em Saúde de Manhiça (CISM), Maputo, Mozambique

Twitter Otavio T Ranzani @otavio_ranzani

Contributors All authors contributed equally to this paper.

Funding OTR is funded through a Sara Borrell grant from the Instituto de Salud Carlos III (CD19/00110). OTR and ALG-B acknowledge support from the Spanish Ministry of Science and Innovation through the 'Centro de Excelencia Severo Ochoa 2019-2023 Program' (CEX2018-000806-S), and support from the Generalitat de Catalunya through the CERCA Program.

Competing interests ALG-B is associated editor of the BMJ Global Health. The other authors have none to declare.

Patient consent for publication Not required.

Provenance and peer review Not commissioned; internally peer reviewed.

Data availability statement The $R$ script to generate this data is available on https://github.com/oranzani/commentaryTB_LA.

Supplemental material This content has been supplied by the author(s). It has not been vetted by BMJ Publishing Group Limited (BMJ) and may not have been peer-reviewed. Any opinions or recommendations discussed are solely those of the author(s) and are not endorsed by BMJ. BMJ disclaims all liability and responsibility arising from any reliance placed on the content. Where the content includes any translated material, BMJ does not warrant the accuracy and reliability of the translations (including but not limited to local regulations, clinical guidelines, terminology, drug names and drug dosages), and is not responsible for any error and/or omissions arising from translation and adaptation or otherwise.

Open access This is an open access article distributed in accordance with the Creative Commons Attribution Non Commercial (CC BY-NC 4.0) license, which permits others to distribute, remix, adapt, build upon this work non-commercially, and license their derivative works on different terms, provided the original work is properly cited, appropriate credit is given, any changes made indicated, and the use is non-commercial. See: http://creativecommons.org/licenses/by-nc/4.0/.

\section{ORCID iD}

Otavio T Ranzani http://orcid.org/0000-0002-4677-6862

\section{REFERENCES}

1 World Health Organization-WHO. Global tuberculosis report, 2020. Available: https://apps.who.int/iris/bitstream/handle/10665/336069/ 9789240013131-eng.pdf [Accessed 1 Dec 2020].

2 Economic Commission for Latin America and the Caribbean (ECLAC). Social Panorama of Latin America 2019. Santiago: UNITED NATIONS, 2020. https://repositorio.cepal.org/bitstream/handle/ 11362/44989/1/S1901132_en.pdf

3 Standley CJ, Chu E, Kathawala E, et al. Data and cooperation required for Venezuela's refugee crisis during COVID-19. Global Health 2020;16:103.

4 Natalino M. ESTIMATIVA dA POPULAÇÃO em SITUAÇÃO de RUA no BRASIL (SETEMBRO de 2012 a MARCO de 2020). technical note, IPEA, 2020. Available: https://www.ipea.gov.br/portal/images/ stories/PDFs/nota_tecnica/200612_nt_disoc_n_73.pdf [Accessed 1 Dec 2020].

5 Walter K, Martinez L, Arakaki-Sanchez D, et al. The escalating tuberculosis crisis in central and South American prisons. The Lancet 2021;397 in press.

6 Sequera VG, Aguirre S, Estigarribia G, et al. Increased incarceration rates drive growing tuberculosis burden in prisons and jeopardize overall tuberculosis control in Paraguay. Sci Rep 2020;10:21247.

7 Herrera M. T. Las posibles causas del aumento de la incidencia de la tuberculosis en Chile. Rev. chil. enferm. respir. 2020;36:51-61.

8 Moreno R, Ravasi G, Avedillo P, et al. Tuberculosis and HIV coinfection and related collaborative activities in Latin America and the Caribbean. Rev Panam Salud Publica 2020;44:e43:1. 
9 Castro AZde, Moreira AR, Oliveira J, et al. Clinical impact and cost analysis of the use of either the Xpert MTB Rif test or sputum smear microscopy in the diagnosis of pulmonary tuberculosis in Rio de Janeiro, Brazil. Rev Soc Bras Med Trop 2018;51:631-7.

10 Saunders MJ, Tovar MA, Collier D, et al. Active and passive casefinding in tuberculosis-affected households in Peru: a 10-year prospective cohort study. Lancet Infect Dis 2019;19:519-28.

11 Rossetti ML, Almeida da Silva PE, Salvato RS, et al. A highly rifampicin resistant Mycobacterium tuberculosis strain emerging in southern Brazil. Tuberculosis 2020;125:102015.

12 Ranzani OT, Rodrigues LC, Bombarda S, et al. Long-Term survival and cause-specific mortality of patients newly diagnosed with tuberculosis in São Paulo state, Brazil, 2010-15: a population-based, longitudinal study. Lancet Infect Dis 2020;20:123-32.

13 Dodd PJ, Yuen CM, Jayasooriya SM, et al. Quantifying the global number of tuberculosis survivors: a modelling study. Lancet Infect Dis 2021:S1473309920309191.

14 Lozano R, Fullman N, Mumford JE, et al. Measuring universal health coverage based on an index of effective coverage of health services in 204 countries and territories, 1990-2019: a systematic analysis for the global burden of disease study 2019. The Lancet 2020;396:1250-84.

15 de Souza LEPF, de Barros RD, Barreto ML, et al. The potential impact of austerity on attainment of the sustainable development goals in Brazil. BMJ Glob Health 2019;4:e001661. 